

Germaine Buckley, Chloé (2020) A tale of two women: the female grotesque in Showtime's Penny Dreadful. Feminist Media Studies, 20 (3). pp. 361-380. ISSN 1468-0777

Downloaded from: https://e-space.mmu.ac.uk/622545/

Version: Accepted Version

Publisher: Taylor \& Francis

DOI: https://doi.org/10.1080/14680777.2019.1583263

Please cite the published version 


\section{A Tale of Two Women: The Female Grotesque in Showtime's Penny Dreadful}

\section{Introduction: Penny Dreadful as Postfeminist Media}

The UK-US television series, Penny Dreadful (Showtime, 2014 - 2016) exemplifies the contradictions of postfeminist media. The series is one of many recent productions to make "canny" use of the gothic mode, knowingly evoking its literary history to produce new stories in a reimagined setting. Other examples include Grimm (2011 - 2017), American Horror Story (2011 - Present), Hemlock Grove (2013-2015), Salem (2014 - 2017), and The Frankenstein Chronicles (2015 - Present). Penny Dreadful borrows from literature, using characters such as Victor Frankenstein, Dracula and Dr Jekyll, but also from popular horror cinema, drawing inspiration from classic monster movies such as The Wolfman (1941). The series also evokes fairy tale and other ephemera, including the sensational nineteenth-century "Penny Dreadfuls" from which the show takes its name. The result is a self-aware NeoVictorian gothic fantasy that celebrates and problematizes the tropes it borrows. Central to Penny Dreadful's ambivalence is the figure of the "female grotesque," which I argue is central to unpicking to complexities of contemporary postfeminist media culture.

The show deploys different gothic tropes to explore representations of femininity and female bodies. Though the show playfully evokes the gothic, it does so through the aesthetics of the grotesque and the abject, two forms that remain politically undecidable. Theories of the grotesque and the abject, which are interrelated concepts, variously characterise them as either radical or conservative, as deconstructive or normalizing processes, providing moments of uncomfortable reflection or pleasurable spectacle. This political ambiguity is a result of the unstable boundaries that the grotesque and the abject draw between the high and the low. Indeed, Penny Dreadful emerges from what Peter Stallybrass and Allon White identify as a "complex cultural process whereby the human body, psychic forms, geographical space and the social formation are constructed within interrelating and dependent hierarchies of high and low" (1986, 2). In Penny Dreadful, "low" cultural forms (dreadfuls, sensation fiction, and "unauthorised" adaptation) are framed by the cultural capital that is attached to highproduction-value serial television. This is "quality television," a form that Lagerney, Leyda and Negra (2016) note anchors middle class tastes and cultural literacies through its reference to literature and cinema. In this appeal to middle-class audiences, Penny Dreadful shores up cultural and class boundaries even as it indulges in visual "bad taste." 
Through its juxtaposition of contrasts, Penny Dreadful explores storylines of oppression and exploitation, weaving a complex web of feminist, antifeminist and postfeminist ideas. In so doing, the show points to the tensions inherent in postfeminist cultural production. These remain unresolved through the three seasons. Rosalind Gill suggests that contemporary media offers "contradictory" constructions of femininity, the female body and feminism (2007, 161). Elements of this "postfeminist sensibility" are present in Penny Dreadful. These include the representation of femininity as bodily property, rather than structural, social or psychological; an "obsessional preoccupation with the body;" a shift in sexualisation from objectification to subjectification, which Gill argues is a "deeper form of exploitation [because] the objectifying male gaze is internalized to form a new disciplinary regime;" the "makeover paradigm," which Penny Dreadful evokes through its version of Bernard Shaw's Pygmalion (1913); and, finally, the use of irony (Gill 2007, 149, 152). This last point is perhaps most complex, because it is through irony that Penny Dreadful attempts to "have it both ways." Sexist abuse is presented as spectacle designed to elicit sensation, but such scenes also suggest that sexism is "safely sealed in the past" (Gill 2007, 160), or else, only exists in the pages of gothic novels.

Uneasy irony features in "Predators Far and Near" (season three), during which Lily Frankenstein and Dorian Gray rescue a girl from a torture den. The girl, a prostitute named Justine, has been tied up, naked, to be tortured to death as spectacle for paying male guests. Lily and Dorian infiltrate the den creating a moment of tension: viewers are aware of Lily and Dorian's transgressive tastes. Perhaps this torture is just another evening's entertainment? Whilst the scene ends with the bloody dispatch of the male spectators at the hands of Lily and Dorian, it also allows viewers to linger on the naked body of the young victim and contemplate the threatened physical abuse from the position of voyeur. The manoeuvres whereby misogyny is made into a bloody spectacle but also represented as a thing of a barbaric past, undercut the ostensible feminist narrative of the scene - the rescue of one imperilled woman (Justine) by an "emancipated" one (Lily). Thus, Penny Dreadful constantly negotiates between feminist principles, the demands of a postfeminist media economy, and the misogyny coded into its visual tropes. The show puts female bodies on display, pathologizes those bodies and evokes problematic dualisms in its parade of female grotesques: prostitutes, femme fatales, madwomen and witches. In its troubling “entanglement of feminist and anti-feminist ideas," Penny Dreadful exemplifies contemporary postfeminist media (Gill 2007, 161). 
A further complication to Penny Dreadful's politics lies in its treatment of social class. The salacious Penny Dreadfuls of the nineteenth century were associated with the working classes and even the cause of a moral panic concerning their ability to provoke criminal delinquency (John Springhall 1994). Penny Dreadful draws on this late-Victorian discourse of classbased criminality, placing female bodies into categories marked by deviancy and degeneracy, separating those belonging to high and low social classes. The most marked separation is between the two main female characters. Brona/ Lily (Billie Piper) is a consumptive prostitute-turned-Bride-of-Frankenstein, who is placed in an "Eliza Doolittle" role before becoming an avenging femme fatale. Vanessa Ives (Eva Green) is an upper-class sensitive revealed to be the incarnation of an ancient Egyptian Goddess and central to a timeless struggle between the powers of Good and Evil. Whilst Vanessa transcends to saintly martyrdom in the final season of the show, becoming a classical body, Brona/Lily represents the grotesque. ${ }^{1}$ Her body is made and remade abject by various male suitors, escaping one low condition only to find another. Though the two women often switch positions through acts of "drag" in which they dress up and down to infiltrate different milieu, by the end of the series Vanessa's narrative arc ascends heavenward whereas Brona descends into monstrosity. Finally, she is side-lined altogether. The different roles allotted to Brona and Vanessa reinforce dualistic notions of "woman" and markedly separate the "classical" from the grotesque, the "clean" from the "abject."

\section{"Painfully Conflictual": The Female Grotesque and Abjection}

The grotesque and the abject are interrelated terms that designate content and style within the text, but they are also ways of theorising what is presented onscreen. Both terms are deeply ambivalent and emerge as central preoccupations of Penny Dreadful, which articulates to an exemplary degree the ambivalence of postfeminist media. My intersectional reading of the

\footnotetext{
${ }^{1}$ My definition of the "classical body" is taken from readings of Stallybrass and White, Mary Russo (1994), and Richard Dyer (1997) whose works refers to art, cinema, and literature. Stallybrass and White argue that the "classical" body functions in opposition to notions of the grotesque in a mutually constitutive, binary system of representation $(1986$ 16, 21). Following this, Russo describes the classical body as transcendent and monumental, closed, static and self-contained, symmetrical and sleek: it is identified with the "high" or official culture of the Renaissance (in art) and later, with the "rationalism, individualism, and normalising aspirations of the bourgeoisie" $(1995,8)$. Dyer links the classical body, an artistic representation in Western art and culture that hails from classical antiquity, to "socially white" ideals such as purity, cleanliness, beauty and civilisation $(1997,78)$.
} 
grotesque and abject in Penny Dreadful accounts for the ways that contemporary discourses of race and social class play out through representations of the female body.

Although Brona and Vanessa are separated by the narrative arcs and visual taxonomies, they are both representatives of what Mary Russo identifies as the Female Grotesque (1994). In the context of its neo-Victorian setting, the show suggests that both women deviate from normalizing gender ideologies, that they are in some way exceptional. In Russo's words, they are the "odd, frightening women" of the freak show, though here placed front and centre, rather than "stashed" or hidden away $(1994,51)$. This strategy seems to endorse feminist politics in its celebration of rebellious women, but it also evokes deeply misogynist ideas about monstrous women. The ambivalence of the female grotesque originates in the undecidable politics of the grotesque as a cultural mode. The grotesque can figure bodies as open and dynamic in the transgressive mode of the carnivalesque as it appears in the work of Mikhail Bakhtin (1984). However, as Russo asserts, though the grotesque has suggested a positive and powerful figuration of womanhood in its association of woman with the earthy and material, it is an "easy and perilous slide from these archaic tropes" to the misogyny which identifies woman with the visceral detritus of the body (1994, 1-2). Thus, Russo suggests, the female grotesque is a "painfully conflictual" figuration $(1994,159)$. This conflict plays out across the female characters in Penny Dreadful precisely because they are caught up in the show's postfeminist contradictions.

Russo's identification of misogynist figurations of the female grotesque in art, literature and critical theory refers to bodily substances connected to the "abject" as theorised by Julia Kristeva (1982): blood, tears, vomit, excrement. Kristeva proposes that such bodily substances disturb the boundaries of the self. This theory of the abject is potentially radical, but works within Freudian discourse, connecting the abject to the so-called "semiotic" or internal pre-linguistic realm of "the mother" $(1982,11,13)$. In this sense, the abject evokes essentialist notions of woman inherited from Freud. Barbara Creed (1993) refers to this figuration of woman in psychoanalysis as the "monstrous feminine," identifying its afterlife in the visual language of horror film, aspects of which also find their way into Penny Dreadful. Thus, the female grotesque and the concept of abjection both reveal a problem in contemporary cultural production. As feminist ideas gain traction in cultural systems of representation, they meet resistance in the form of images that continue to be mired in misogyny. That is, any space opened by the female grotesque within existing systems of 
representation are necessarily limited and risky. To use Russo's metaphor of the trapeze artist, the female grotesque is always moments from breath-taking flight or disastrous fall.

The troubling ambiguity of the female grotesque can easily crystallize into a dualistic representation, suggesting the difficulty in deconstructing misogynist representation onscreen. Writing in the 1970s, M. C. Kolbenschlag identifies an "obsession" with the female grotesque in Hollywood cinema of the period, but is dubious about its power to disturb the status quo. She argues that the "appearance of the female as 'grotesque' in films is in part the obverse of the phenomenon of directorial narcissism," since the main interest of such films is men and not women $(1978,328)$. Kolbenschlag also notes that misogyny has its roots in the dualistic distinctions Western thought imposes on reality: distinctions between mind and body, reason and emotion, spirituality and carnality. Penny Dreadful may not display the "directorial narcissism" of 1970s Hollywood, but it does draw on these dualisms. This is notable in the opposition of Vanessa and Brona. Whilst Vanessa's body is important in the narrative, and she, like Brona, becomes the subject (as well as object) of sexual desire, the main plot centres on a fight over her soul. Vanessa's bodily suffering is a side-effect of a spiritual war. In contrast, Brona's body determines her narrative trajectory. She is also presented far more frequently as an object rather than a subject, literally formed into a monster by Frankenstein's experiments. Dualism is also present in the gothic tropes evoked in the characterisation of these women: prostitute, witch, femme fatale and mad woman to name a few. These character tropes derive from a cultural system that constructs woman both as the subordinate half of a duality (man/woman), and via the dualistic image of Virgin/Whore. Sandra Gilbert and Susan Gubar famously refer to this duality in the male literary tradition as the "extreme images of 'angel' and 'monster'" $(2000,17)$. Penny Dreadful struggles to transcend these binary extremes.

The separation of Brona/Lily from Vanessa reveals a further problematic at the heart of the show's representational logic. Though both women are made abject at various points (in the sense evoked by Kristeva) through their connection to bodily substances, Brona is specifically abjected in ways that recall Georges Bataille's original formulation of the term in his essay, L'Abjection et les formes misérables (1993 [1934]). For Bataille the abject is a process of exclusion that establishes class hierarchy through spatializing aversion and discourses of disgust $(1993,10,12)$. The abject names class-based processes of dehumanization in which people become things, not, as Kristeva would have it, the 
primordial and essential psychological condition of subjectivity (Sylvère Lotringer 1993, 3). Bataille's notion of the abject offers another perspective on Penny Dreadful, suggesting its complicity with wider discourses about social class in contemporary U.S. and U.K. cultures. Imogen Tyler reveals how discursively constructed images of working class excess evoke disgust, manufacturing consent for social inequality in the media $(2008,18)$. Jeffrey Brown (2005) notes a similar discourse operating in the U.S. in his analysis of media coverage about "playboy playmate" Anna Nicole Smith. Brown shows how the media evokes the idea of "white trash" through images of bodily excess in a process of abjection that naturalizes class difference through the female body $(2005,3)$. Penny Dreadful is very different to the exploitative media Tyler and Brown examine, but its demarcation of social class operates within the same contexts, in which the abjection of class intersects with representations of the female body. Penny Dreadful adds to this (re)mediated Victorian discourses about class and femininity, further entangling its muddle of feminist and antifeminist ideas.

\section{Vanessa Ives: Madness, Punishment, Sacrifice}

Vanessa Ives is a complex figure, shifting from the risky role of female grotesque into states of outright abjection in scenes of madness and bodily suffering. A devout Catholic, her character also evokes early Gothic literature, which abjected and exoticized European Catholicism. Yet, Vanessa is also the heroine of the show and is accorded the status of "classical body" as her narrative develops. Hers is a character that demonstrates remarkable mobility, though such shifts through aesthetic and narrative positions are not always the result of her agency. Vanessa is also an unwilling spirit medium, and the reincarnation of an ancient Egyptian deity, Amunet. The show presents her by turns a saintly figure and then a demonic one. Her initial appearance is dominated by clipped self-possession and control, denoted by constrictive, high-necked clothing and a swept-up hairstyle. Later, Vanessa casts off this selfpossession when demon possession takes hold and she goes into the streets to find sexual gratification [Fig 1]. In season two, Vanessa's corseted upper-class femininity, denoted by fussy lace and jewelled adornments, is abandoned for the rustic attire of the rural hedgewitch, or "cut wife", which she dons when seeking refuge from demonic pursuers in a cottage in the West Country ("The Nightcomers," season two) [Fig 2]. Shifting through these different aesthetics, Vanessa suggests the performative nature of femininity. However, this revelation of performativity is not in itself liberation from the limits imposed by the roles she plays. Also, such performative mobility is afforded Vanessa partly due to her class status, 
which allows her to play roles below her elevated station. The "cut wife" garb is a particularly striking example of such lower-class "drag" and it is swiftly replaced with the sumptuous fabrics and refined dress that marks Vanessa's true station once she returns to London. The reverse occurs in the case of Brona's performance as Lily Frankenstein, with the show suggesting that these women belong in different spheres. In Vanessa's case, she fails to find a role that suits, and the narrative trajectory limits her mobility as it reaches its climax.

FIG 1: [LEFT] Vanessa in restrictive clothing, hair swept back. [RIGHT] Vanessa abandons the soiree, hair loose, gown drenched.

FIG 2: Vanessa as "cut wife."

One of the more troubling roles adopted by Vanessa is that of madwoman. Costumed in the straitjacket of the asylum inmate in "A Blade of Grass" (season three), or, in dirty shift, hair in disarray, confined to her room in combat with a demon, during "Possession" (season one), Vanessa as madwoman reveals the ways that performativity becomes fetishization onscreen. The depiction of Vanessa as a madwoman embraces the substances of abjection identified by Kristeva. The blood and grime smeared on Vanessa's clothing and body contrast with her usually clean, classical body and feminine beauty. In its evocation of the abject, Vanessa's madwoman costume provokes questions about, and critiques of, a discourse of female mental illness that, historically, has been used to subjugate unruly women. Flashback sequences from Vanessa's forced incarceration in an asylum clearly depict the treatment of women as brutal and repressive. However, Vanessa as madwoman also makes a fetish of her abjection, revealing Bataille's assertion that the process of abjection imposed from above can elicit a perverse and masochistic will to humiliation and sainthood, which works at the expense of engaging in real struggles against oppression (1993, 9). In "Possession" (season one), Vanessa gives her body to this masochistic humiliation to the point of death in submission to the will of the family patriarch, Sir Malcolm (Timothy Dalton). Scenes of her battered and emaciated body function to titillate as well as critique, indulging in a spectacle of punishment upon the deviant female body [FIG 3]. 
As madwoman, Vanessa also suggests the longstanding connection between women and madness in Western culture. Elaine Showalter argues that this connection developed during the Victorian period through a medical discourse that linked insanity to the biological crises of the female body $(1987,55)$. Pseudo-Darwinian thinking added a class dimension in the association of madness with moral degeneracy, a fate to which lower class women were seen as doubly susceptible (Showalter 1987, 18). Showalter also notes that a language of monstrosity, influenced by gothic literature, characterised madness discourse of the period. One report on Lunatic Asylums from 1857 envisioned madness as the monster "which appalled Frankenstein" (Andrew Wynter, quoted in Showalter 1987, 25). Penny Dreadful evokes this link to Frankenstein when it depicts Vanessa inside the madhouse with a character called John Clare (Rory Kinnear) as her warden. During this flashback segment, viewers are aware that Clare, named for the working-class Romantic poet, is fated to become Doctor Frankenstein's creature, "Caliban.” Later, viewers witness the degraded poverty in which Clare's family languish. The class position of Caliban and Brona makes their bodies ripe for exploitation by the Doctor. Their suffering at his hands (as well as that of an uncaring society) seems to explain their descent into madness: both become murderous and impulsive, intent on revenge. Yet, the representation of their madness contrasts with that of Vanessa's, which is woven into a narrative about her victimhood and subsequent self-denial and sacrifice, which is denoted by bodily rather than social abjection.

The involvement of Vanessa and Brona in class-inflected madness plots illustrates aspects of Russo's theorisation of the female grotesque. She notes that "the figure of the female hysteric, ungrounded and out of bounds $[\ldots]$ is as foundational to psychoanalysis as the image of the 'senile, pregnant hags' is to the Bakhtinian model of grotesque realism" $(1994,9)$. In both psychoanalysis and the grotesque, then, women figure as monstrosity. Though this monstrosity might serve as a potential site of resistance, in nineteenth-century medical discourses, the figure of the hysteric shores up notions of normality. That is, normality is paradoxically established through the difference that madwomen demonstrate from normal, healthy women (Russo 1994, 9; Showalter 1987, 63). Likewise, in Penny Dreadful performances of hysteria become spectacles designed to elicit fascination and disgust. This is not grotesquerie in a positive Bakhtinian sense, "representing all the people" $(1984,19)$, but the spectacle of a freakish woman performing an exception to normality. Vanessa's reference to "this thing inside me" (season one) suggests the cavernous interior space of woman, 
further rehearsing gothicised Victorian discourses of female madness with the suggestion that madness inheres in female bodies.

Vanessa's performance as a madwoman represents an extreme deviation from the norms of feminine beauty, but even when she is costumed in the sumptuous gowns of the upper-class beauty or fussy lace evoking bourgeois tastes, Vanessa is never quite perfect. She is pale, sickly, too thin, excessive in her intensity. In her analysis of nineteenth-century asylum photography, Showalter argues that this deviant aesthetic became fetishized through the male gaze $(1987,94)$. The wasting pallor of the melancholic young woman, costumed in a suitably awry shift and posed by the photographer, was descried in psychiatric accounts as "oddly feminine and attractive" (Showalter 1987, 94). This same doctor recounted his disappointment with the patient in question once she had recovered her weight, noting she had declined in sexual magnetism as well as class status. In Showalter's account it seems that some versions of female grotesquerie are more appealing to a male gaze than others. The pallor of the sick woman strangely evokes the white marble of classical art, but a plump form threatens to be too much, prefiguring modern media constructions of lower-class women which also emphasize excess weight as a marker of class difference (Brown 2005, 80; Tyler $2008,28)$. These class-inflected discourses of beauty and madness play out in the depiction of Vanessa, who descends into the filth of bodily abjection during her forays into madness, but remains incredibly slender, with prominent cheekbones and a bone-white complexion. The ambiguity surrounding Vanessa's body supports Gill's argument that postfeminist media is entangles feminism with anti-feminism. Vanessa's unconventional appearance and characterization clearly undoes the stereotype of Victorian angelic femininity. Yet, she is sacrificed in the name of those ideals. In a poignant fantasy sequence, Vanessa experiences domestic bliss with her lover Ethan Chandler (Josh Hartnett) and their imaginary children, a scene of white lace, soft furnishings and sunlight [FIG 4]. Vanessa does not refuse this vision as an act of rebellion. Rather, she embraces a narrative in which her deviancy and corruption require self-denial and self-sacrifice. This is the conservative function of the female grotesque.

FIG 4: A soft-lit fantasy sequence.

Vanessa's oscillation between states of abjection and beauty, and her eventual shift from a figuration of the female grotesque to that of classical body, complicates her juxtaposition 
with Brona. The key distinction is social abjection. Clearly, Penny Dreadful connects both women to bodily abjection. There are, for example, mirroring sequences that show the women bathed in blood [FIG 5]. Both women also indulge in social "drag," where Vanessa plays at being the "cut-wife," Brona plays the role of Lily Frankenstein. As female grotesques, neither women have stable identities, but operate as figurations of the conflicting dualisms inherent in patriarchal constructions of femininity. The messy overlaps between the women, though, do not dissolve their ultimate separation. Despite her periods of bodily abjection, Vanessa is easily recuperated into the realm of high culture. A quick costume change, and she moves with ease amongst London's social elite. However, Brona's presence in that world is a dangerous act, for herself and others. Oftentimes, she is depicted as a corrupting presence that brings with it the chaos of the streets. In a rare scene together in "Above the Vaulted Sky" (season two), the women perform feminine delicacy over afternoon tea with Dr Frankenstein. Vanessa is at ease, but Brona is uncomfortable, looking nervously to Frankenstein for direction. The two women are visually contrasted, too, in cream and brown outfits [FIG 6].

FIG 5: [LEFT] Vanessa experiences a vision of herself and others bathed in blood. [RIGHT] A blood-bathed sex scene between Vanessa, Dorian and Justine following their murder of a pimp.

FIG 6: Visual contrast between Lily and Vanessa.

In this dimly lit show, Vanessa's whiteness is luminous. When it is not covered in the filth of bodily abjection, her bone-white skin signifies the classical body of Western art, shoring up hierarchies of social class and race. Exploring representations of beauty and whiteness in Western culture, Richard Dyer notes how Victorian photography used light and dark to emphasize whiteness and so racialize class difference: “a middle or upper-class woman's face might be rendered nearly as white as the paper on which it was printed or the screen on which it was projected" $(1997,113)$. Dyer traces this representation of whiteness as the "pinnacle of human beauty" through art, photography, and film and many of his observations map directly onto techniques employed in Penny Dreadful $(1997,72)$.

Due to her upper-class whiteness, Vanessa is recuperated from grotesquerie and restored to an elevated position through a narrative of transcendence and martyrdom. Fighting for possession of her soul with ancient demonic forces, Vanessa chooses death, and asks her 
lover to kill her before she can bring about the end of the world. Vanessa submits to this tragic death surrounded by candles, dressed in a pale, flowing gown evoking imagery of Greco-Roman statuary [FIG 7]. The final image shows a classical body restored to its "elevated, static and monumental" status (Stallybrass and White 1986, 21). Here, Vanessa is sacred and untouchable, having sacrificed a physical relationship with Chandler to stave off demonic temptation. The lovers' self-denial contrasts with the lusty physicality of the relationship between Brona and Chandler from season one. The trajectory of Vanessa and Ethan's spiritual storyline, along with the celestial aesthetic of its tragic climax, also transports Vanessa from the human plane to a zone where she becomes "frozen and universal" (Stallybrass and White 1986, 21). Vanessa is removed from a temporal structure through a universalised narrative about the immortal battle between good and evil.

FIG 7: Finale.

As the ritualistic imagery of these scenes suggests, the classical body is also a sacred body in which whiteness mingles with notions of spirituality. Dyer argues that images of whiteness recall a Christian dichotomy of body and spirit, suggesting that the Virgin Mary functions as the "white ideal" in her role as the vessel for God's spirit (1997 15, 16-17). Throughout Penny Dreadful, Vanessa has functioned as a vessel for spirits of less holy provenance, her demonic possession suggesting the cavernous interior of the female grotesque. Here, though, the character serves an explicitly White Christian aesthetic, her suffering and self-denial exemplary of all that respectable white women must strive.

Other key tropes of whiteness identified by Dyer are clearly present in Vanessa's final moments: the association of white with light, the image of the incapacitated feminine body held by a muscular white male body, and, finally, the deathliness of the white body necessary for its transcendence (Dyer 1997, 14). Dyer argues that the association of white with light privileges whiteness as transcendent and hierarchically dominant because light comes from above $(1997,84,88)$. Penny Dreadful echoes these associations as the candles bathe Vanessa's pale body and gown in light. The camera looks down on her prone form from above. The image of a darkly dressed man carrying a woman robed in white echoes decades of Hollywood cinema that has privileged the glowing white woman (Dyer 1997, 88). Chandler, a "wild west" American, is also a figuration of imperialism. Dyer notes the importance of the Western myth, one variation of the imperial adventure narrative, in 
establishing the dominance of whiteness in Western culture. In these imperial narratives, the incapacitated feminine body works in concert with a muscular white male body (Dyer 1997, 32). In this final sacrifice, the scene closes Vanessa from further transformation. No longer grotesque, Vanessa has become a sealed, sepulchral figure - her whiteness echoing centuries of art that venerates the dead, white body (Dyer 1997, 204). In death, Vanessa becomes that highest of Victorian ideals: the white woman as angel (Dyer 1997, 127). Yet, this idealised image represents an impossibility. Thus, Penny Dreadful's closing scene remains difficult to read, providing further evidence of the show's postfeminist tensions. Vanessa's sacrifice is either a repudiation of the dualisms that have long served to 'carve up' women in literature and onscreen, or else as a fetishized spectacle of martyrdom that makes a saintly object from the body of the white woman.

\section{Brona Croft: Filthy Femme Fatale}

In death, Vanessa is aligned with spirit not body, completing her elevation from female grotesque to classical body, closing off the mobility her position as a grotesque afforded. In contrast, Brona/ Lily remains anchored to her body, a body implicated in the economic exchange of prostitution, gendered violence and political struggle. Brona is the grotesque body par excellence since she is "never closed off from either its social or ecosystemic context" (Stallybrass and White 1986, 22). Instead of a universalizing narrative about good and evil, Brona's plots explore the banal violence and tragedy faced by lower class women. In "Perpetual Night" (season three) Brona relates the experience of leaving her crying infant in front of a fire in her lodgings on a freezing winter night to go in search of a punter, returning later to find the infant frozen to death. Brona's various bodily incarnations (Chandler's grieving prostitute, Frankenstein's naive companion, and Dorian's femme fatale) also exemplify the grotesque in terms described by Russo. Whilst the classical body is closed and static, the grotesque body is "open, protruding, irregular, secreting, multiple, and changing" (Russo 1994, 8). In season one, Brona drinks with Ethan in a dockside bar, before taking him to bed. She also has sex with Dorian during a photography session, coughing up blood during the act, a reminder of the consumption ravaging her body [FIG 8]. Later, Brona is resurrected, taking on the identity of "Lily Frankenstein." These multiple selves continue to be changeable and porous. In "And They Were Enemies" (season two), blood leaks from a wound on Lily's chest, pours down her satin dress and smears across the floor of the 
ballroom where she dances with Dorian [FIG 9]. Whereas grotesque bodily secretions are aligned with "social transformation" in the Bakhtinian grotesque (Russo 1994, 8), in Penny Dreadful they signify the monstrous. Like Bataille's social abjects, Brona is "unable to fend off contamination by filth" (Bataille, 1993, 4).

FIG 8: Frankenstein murders Brona.

FIG 9: Lily dances with Dorian.

Brona is a revolting body in the double sense of that word. As well as being presented as an object of grotesquerie, she revolts against the abject conditions in which she is placed. Tyler notes this doubled nature of abjection as both a discourse of aversion that produces consent for social inequality and a form of revolt to which this inequality gives rise $(2013,5)$. Brona is made abject by but also revolts against Chandler, Frankenstein and Dorian, all of whom seek to use her for their own ends. Finally, she becomes an avenging femme fatale, recruiting an army of murderous ex-prostitutes in her war against men. Briefly, Penny Dreadful connects Brona's revolution with the protests of a group of suffragettes, but the connection is quickly dismissed by Brona who scoffs at the polite demonstration. In contrast to the bourgeois suffragettes, Brona's lower-class revolt makes use of her sexual body, represented as the essential source of her femininity riven by blood and violence. Rather than agitate for social or political change, Brona seeks grim retribution on individual men whom represent a system of sexual exploitation. In "Little Scorpion" (season two), "Lily" escapes Frankenstein's attic and murders a man who propositions her in a pub. Prostitution, illness, incarceration and abuse are inescapable contexts that transform her female grotesquerie into social abjection, contaminating her with filth of which the middle-class suffragettes have no knowledge.

Through Brona's monstrosity, Penny Dreadful critiques but also contributes to abjection as the process of becoming thing-like, of dehumanization. Again, the show entangles antifeminist images of abjection and objectification with feminist ideas such as the performativity of gender and class. The process of becoming thing-like begins for Brona almost immediately, when she is introduced via a sexual encounter with Chandler. In "Séance" (season one) Chandler comments on what he views as Brona's authenticity: "I like things to be what they are" he tells her approvingly. Though her prostitute persona is clearly 
performative, Brona is objectified by Chandler who locates in her performance an "authenticity" dependent on Brona's degraded economic circumstances. Actually, it is Brona's mouldable grotesquerie that allows Chandler to indulge in his own performance of lower-class villainy. (Much later, Chandler reveals his wealthy origins and, accordingly, his affections switch to Vanessa). As the series progresses, Brona becomes different things for different men: she performs briefly as Frankenstein's bourgeois cousin/wife and then as alluring femme fatale for Dorian Gray, her mouldability in these roles contrasting with Vanessa's essential specialness as the vessel of an ancient goddess.

Brona's transformations are also wrought by the desires and actions of male characters. Her transformation into monster literalizes the process of abjection as dehumanization. Though Penny Dreadful seems at pains to excuse Frankenstein's murder of the ailing Brona as a mercy killing, it is quite clear that he wants her body for his experiments and to fulfil his bargain with Caliban. In this process, Brona becomes an object of exchange between two men. After the murder, Frankenstein fondles Brona's corpse in his laboratory, her body scarred with his knife marks [FIG 10]. Through this process, Brona is "disinherited from the possibility of being human" (Bataille 1993, 11). From this point, her narrative charts a trajectory towards monstrosity, precluding her from the recuperation and transcendence offered Vanessa. Brona's transformation into a monster also suggests that once people are placed in the domain of things there is little opportunity for self-affirmation.

FIG 10: [LEFT] Frankenstein touches Brona's corpse. [RIGHT] Brona emerges from the water as the camera pans up her naked form.

Brona's transformations are markedly different from the conscious self-fashioning performed by Vanessa. In a dark parody of George Bernard Shaw's Pygmalion, "Verbis Diablo" (season two) shows Frankenstein costume and tutor his new monster so she can serve as his bourgeois wife. Brona's "makeover" serves in part to deconstruct the process whereby women mould themselves into objects for male gaze, revealing femininity as performed through costume and behaviour. ${ }^{2}$ Chosen by Frankenstein, the name Lily denotes

\footnotetext{
2 Though Mulvey's term 'the male gaze' has been disputed since its theorisation in 'Visual Pleasure and Narrative Cinema' (1975), I evoke it here to emphasize that postfeminist media still offer representations that objectify women as objects for male heterosexual consumption. My use of the term rejects the psychoanalytical baggage, which constructs women in opposition to men via a Lacanian/ Freudian discourse of 'lack,' but recognizes its usefulness as a shorthand for the ways contemporary media sorts, costumes, packages, airbrushes and poses female bodies. The collective 'vernacular' feminisms discussed by Lagerney, Leyda and Negra
} 
stereotypical flowery femininity. Frankenstein also washes Lily, cuts her hair into soft curls, and clothes her in dusky pink and neat lace, suggesting a demure femininity, before displaying her at a social gathering as his "cousin" (a reference to Mary Shelley's novel). Frankenstein is aided in this makeover by Vanessa, who directs him to suitable clothes and tutors Lily in etiquette. There is a knowing aspect to this plot. In one shot, Lily looks directly at the camera whilst holding a hand mirror; in another she murmurs lovingly to Frankenstein, "You're making me into an angel." The hand mirror functions as a visual metaphor of objectification, and Lily's direct gaze is deliberately challenging. Kaja Silverman notes that "the image of a woman in front of a mirror, playing both to the male look and her own, has become a familiar metaphor of sexual oppression" (1986, 139). Indeed, Frankenstein's makeover of Lily is motivated by his desire to possess her body. Lily seems alert to this, her "angel" comment a knowing reference to the Victorian ideal of the "angel in the home." Lily signals her awareness of the obverse of this idealised image, acknowledging that Frankenstein also desires her body as a sexual object, complaining about his choice of highheeled shoes.

Yet, the irony of the "Pygmalion" plot is undercut by multiple postfeminist manoeuvres. Foremost, there is the imperative of the show to turn Lily's makeover into a spectacle, the camera lingering on her waist, legs and breasts at multiple opportunities. Lily's complaints about corsetry also suggest that her experiences of sexism and objectification are particular to Victorian society, and, so, safely sealed in the past. This is a postfeminist manoeuvre because it contrasts a barbaric past in which the character resides with the supposed enlightened present of the viewer. Likewise, Lily's sexual seduction of Frankenstein suggests the shift from objectification (via a male gaze) to subjectification. "Lily" escapes objectification by asserting what seems to be her sexual agency, but, in so doing, she becomes monstrous and the show suggests viewers sympathies might lie with the manipulated male characters who have become victims of her inscrutable desire. After Lily has bedded Frankenstein, she pours mocking scorn on Caliban, asking him what he wants from her. His reply suggests Lily is unfeeling: "What I want I cannot have. You're incapable of it." The camera lingers on her

(2016), mobilised by hashtags and social media campaigns, continue to find value in the idea of the male gaze in its broadest sense. That male bodies are equally sexualised in Penny Dreadful is also true, but my concern here is the cutting of female bodies in a visual sense, which supports a narrative of social abjection and dehumanisation. 
fractured reflection in this moment, suggesting the shattering of her idealised feminine persona and the multiplicity and duplicity of her character [FIG 11].

FIG 11: "Lily" becomes fractured in "Memento Mori"

The failure of the "Pygmalion" plot widens the gulf between Brona and Vanessa. Revealing that her naivety was a ruse, Lily casts off the veneer of demure femininity and returns to Dorian Gray, a former client. Penny Dreadful's treatment of Lily's (re)turn evokes aspects of contemporary media representations of working class and "white trash" women. For example, Brown argues that former Playboy "playmate," Anna Nicole Smith, was punished in the U.S. media for exceeding her class status when she married a millionaire. Smith came to embody the stereotype of "white trash" as bodily and sexual excess $(2005,76)$. Tyler notes similar elements in the stereotypical media representations of working-class women in the U.K., which likewise emphasise their unruly sexuality and bodily excesses (2008). Though the setting is very different, Penny Dreadful's depiction of Brona echoes these media discourses in Brona's swift abandonment of domesticity for murderous sexual encounters. Brona is tied to the carnal nature of her body, which is associated throughout with blood and violence. Penny Dreadful is careful to ensure sympathy remains with Brona, but aspects of her characterisation suggest the essential nature of class difference in ways that echo broader media discourses of femininity and social class.

As well as echoing contemporary representations of social class, Penny Dreadful evokes late Victorian ideas about the moral weakness of the lower classes. Again, this emerges through the show's treatment of the madwoman. The transformation of Lily wrought by Frankenstein and Vanessa recalls psychiatric treatment of the period, which included "taming" prostitutes and other "madwomen" by moulding their dress and behaviour to mimic bourgeois tastes and social norms (Showalter 1987, 79). Showalter notes that "Victorian madwomen became subject to the moral management of their appearance" and "sanity was often judged according to their compliance with middle-class standards of fashion" $(1987,84)$. Later in the series, Dorian and Frankenstein suggest that Lily has become mad when she exceeds their control and management. They capture her, taking her to the depths of Dr Jekyll's asylum, where she is strapped to a chair so they can administer a serum that will correct her defects. Here, Brona's former suitors seem to represent outdated views on female sexuality, their desire to control the unruly woman through medical treatment echoing Victorian male 
psychiatrists" "fears of female sexuality" (Showalter 1987, 74). Yet, postfeminist tensions complicate a potential feminist reading and masculine narcissism emerges. Here, Penny Dreadful evokes the 1970s Hollywood trope of the femme fatale "victimizing the beleaguered male" (Kolbenschlag 1978, 338). After all his manipulation and objectification of Lily, Frankenstein becomes a lovelorn figure for whom the show suggests viewers might feel some empathy. When Brona leaves him for Dorian, she mocks his clumsy lovemaking, calling him the "little boy cramming his hand in the sweet jar" ("And They Were Enemies," season two). Here, Frankenstein becomes the "manipulated victim" (Kolbenschlag 1978, 334), whilst Brona is the aggressor.

Although Frankenstein and Dorian's desire to possess and control Brona are represented unsympathetically, for the most part, they remain figures of identification whilst Brona/Lily becomes a figure of fetishization. Tyler's analysis of a range of media representations of lower-class women notes this fetishizing function of abjection, with those who are made abject becoming "fetishistically overdetermined" $(2013,10)$. Already unable to escape her bodily contexts, Brona becomes further overdetermined when she rejects Frankenstein's makeover and chooses to become a femme fatale. In this role, Brona/Lily rebels against patriarchal oppression and hypocrisy, against the submissive femininity Frankenstein seeks to impress upon her, and against the social forces that resulted in her degradation as a prostitute. Such a rebellion is monstrous. Nowhere is this clearer than in her dismissal of the suffragettes:

All this marching around in public and waving placards. That's not it. How do you accomplish anything in this life? By craft. By stealth. By poison. By the throat quietly slit in the dead of the night. By the careful and silent accumulation of power. ("Good and Evil Braided Be," season three)

In its evocation of centuries-old images of the illegitimacy and violence of female power, Brona's speech plays into reactionary conceptions of feminism as an anti-men movement. Her dismissal of the "clamorous" suffragettes likewise vocalizes a persistent thread within the show: that "unruly" women are rarely successful. Here, Brona becomes a succubus figure, using her sexuality to enact violent revenge. This monstrous image of female rebellion, which plays to anti-feminist sentiments, has roots in much earlier media. Discussing the femme fatale on 1970s Hollywood cinema, Kolbenschlag $(1978,335)$ suggests 
it is as though men, confronted with an irreversible change in the status and social function of women, are rendered incapable of empathy for them in their new roles and can only deal with the new image by rendering it grotesque.

Though decades old, Kolbenschlag's observations are depressingly relevant to contemporary media, which has seen a proliferation of postfeminist female grotesques. An episode of the BBC series Sherlock (“Abominable Bride”, 2016) costumed its murderous suffragettes in Klu Klux Klan hoods in a clumsy visual analogy that equated feminism with violent prejudice. Brona's revenge plot reveals the difficult task of the female grotesque: how to enact revolt whilst being made into an object of revulsion. The figure of the femme fatale "flips the script" in a typically postfeminist gesture that both articulates and affirms misogynist fears about powerful women.

Having thoroughly confused its representation of Brona/Lily throughout the three seasons, then, Penny Dreadful seems at a loss for what to do with her. Her exit from the show in the final episode is rather anti-climactic. Her army of scorned women have been evicted by Dorian, who tells Brona they have "gone back to where they came from" in "The Blessed Dark" (season three). Justine, however, lies dead by Dorian's hand, on the floor of the grand ballroom. Lily looks sadly at the corpse and muses, "so my great enterprise comes to no more than this: one more dead child." A brief exchange between Dorian and Lily returns the focus to Dorian's fate as a morally bereft and utterly isolated immortal. The camera pans the portraits that adorn the wall, re-anchoring the viewer in the male-focussed narrative of Wilde's novel. When Lily exits, the camera remains on Dorian, centre screen, alone in the ballroom. The reminder of the episode is devoted to the fight between the show's alternative "crew of light" (Frankenstein, Chandler, Sir Malcolm) with Dracula's minions and to Vanessa's death. The post-action sequence charts the devastating affect her loss has on the men in the story and concludes with poetic words from Caliban, Brona seemingly forgotten.

\section{Dreadful Conclusions}

Penny Dreadful is replete with literary references and intertextual awareness, through which it comments on, but is also caught within, a postfeminist media economy that produces female bodies as objects of consumption and all-too-frequently reduces female experience to a side-show in favour of stories of masculine heroism and tragedy. Penny Dreadful's depiction of differently classed women also sometimes works to reinforce gender, race and 
class hegemonies. However, just as the grotesque is neither politically radical nor conservative, the female grotesque remains deeply ambivalent and, so, Penny Dreadful remains neither resolutely feminist nor anti-feminist. Aspects of its representation and characterisation certainly evoke feminist debate and scrutinise problematic modes of representation. My analysis aims not to assess the show in terms of its political utility but instead to show the difficulty that existing representational systems pose for feminist politics. No matter its subversive intent, postfeminist media struggles to refigure misogynist tropes and dualistic stereotypes and to carve out space for female characters to enact transformation. Hence, I believe, the popularity of the female grotesque. Indeed, Penny Dreadful is exemplary of the difficulty intersectional feminist politics has in finding traction in popular culture. At root, this difficulty originates in the polyphonic nature of language and discourse. As Bakhtin asserts, "language is not a neutral medium that passes freely and easily into the private property of the speaker's intentions; it is populated-overpopulated-with the intentions of others" $(1981,294)$. The intentions of Penny Dreadful remain murky, bound up in a media economy that trades on the consumption of female bodies, but even in its more explicitly feminist moments it faces the difficult task of forcing an image - freighted with centuries of misogynist discourse - to serve a new politics.

The tensions I have traced in Penny Dreadful inhere in much contemporary gothic media which draws on a representational system that remains obsessed with "woman" as a dualistic image and continues to articulate the misogynist connotations of tropes such as madwoman, witch and femme fatale. The fact that these images are present in Penny Dreadful suggests that the tradition remains, lurking in seemingly feminist-inspired plots. Through categorisations of unruly women as madwomen and witches, Penny Dreadful also constructs a disciplinary gaze. As Russo notes, "the scrutiny and segmentation of female body types, and the measures, cataloguing and segmentation of different 'models' for different consumption, separate out individual bodies as exceptions that prove the rule" $(1994,10)$. This process of segmentation and categorisation is at work in Penny Dreadful's typology of grotesques, undercutting its suggestions of heterogeneity and performativity. Its women affirm representational norms by posing as exceptions (the transcendent Venessa) or abjections (the monstrous Brona). Thus, although the figure of the female grotesque partly might reconfigure or rehabilitate misogynist tropes, it is a strategy that "involves serious risk" (Russo 1994, 10). 
Penny Dreadful's women emphasizes the precarious status of feminist ideas in popular culture. At the intersection of social class, these feminist ideas become even more precarious. Thus, Brona is perhaps the more complex and ambiguous of the two women, even though she is not the central character. Her complexity highlights Stallybrass and White's notion that the "low" is the "primary site of contradiction, the site of conflicting desires and mutually incompatible representation" $(1986,4)$. I would add that the "low" is also the site of potential evasion. Despite the abjection imposed upon Brona, her lowly position in the text offers an avenue of escape denied Vanessa, who must ascend to status of angel. Brona falls and is made low, but turns this fall into flight, disappearing into the shadowed streets of London one last time. In contrast, the sacred and idolized Vanessa is sacrificed. Perhaps the ultimate frustration of this postfeminist text is that this sacrifice remains opaque. Why must the female grotesque be destroyed?

\section{References}

Bakhtin, Mikhail Mikhaĭlovich. 1981. The Dialogic Imagination: Four Essays by M.M. Bakhtin. Translated and Edited by Caryl Emerson and Michael Holquist. Austin: University of Texas Press.

Bakhtin, Mikhail Mikhaŭlovich. 1984. Rabelais and His World. Translated by Helene Iswolsky. Bloomington, IN: Indiana University Press.

Bataille, Georges. 1993. "Abjection and Miserable Forms.” Translated by Yvonne Shafir. In More \& Less, edited by Sylvère Lotringer, 8-14. Pasadena, CA: MIT Press.

Brown, Jeffrey. 2005. "Class and Feminine Excess: The Strange Case of Anna Nicole Smith." Feminist Review 81: 74-94.

Creed, Barbara. 1993. The Monstrous-Feminine: Film, Feminism, Psychoanalysis. Oxon: Routledge.

Dyer, Richard. 1997. White: Essays on Race and Culture. Oxon: Routledge. 
Gilbert, Sandra M. and Gubar, Susan. 2000. The Madwoman in the Attic: The Woman Writer and the Nineteenth-Century Literary Imagination, $2^{\text {nd }}$ edn. New Haven and London: Yale University Press.

Gill, Rosalind. 2007. "Postfeminist media culture: elements of a sensibility." European Journal of Cultural Studies 10 (2): 147-66.

Kolbenschlag, M. C. 1978. "The Female Grotesque: Gargoyles in the Cathedrals of Cinema." Journal of Popular Film 6 (4): 328-341.

Kristeva, Julia. 1982. Powers of Horror: An Essay on Abjection. Translated by Leon S.

Roudiez. New York: Columbia University Press.

Lagerney, Julie, Leyda, Julia and Negra, Diane. 2016. "Female Centered TV in an Age of Precarity." Genders 1 (2). Accessed December 17, 2018.

https://www.colorado.edu/genders/2016/05/19/female-centered-tv-age-precarity

Lotringer, Sylvère. 1993. "Les Miserables.” In More \& Less, edited by Sylvère Lotringer, 27. Pasadena, CA: MIT Press.

Russo, Mary. 1994. The Female Grotesque. New York: Routledge.

Showalter, Elaine. 1987. The Female Malady: Women, Madness and English Culture 18301980. London: Virago.

Silverman, Kaja. 1986. "Fragments of a Fashionable Discourse." In Studies in Entertainment: Critical Approaches to Mass Culture, edited by Tanya Modleski, 139-54. Bloomington, IN: Indiana University Press.

Springhall, John. 1994. “Pernicious Reading”? The Penny Dreadful as Scapegoat for LateVictorian Juvenile Crime.” Victorian Periodicals Review 27 (4): 326-49.

Stallybrass, Peter and Allon White. 1986. The Politics and Poetics of Transgression. Ithaca, New York: Cornell University Press. 
Tyler, Imogen. 2008. “'Chav Mum, Chav Scum' - Class Disgust in Contemporary Britain.” Feminist Media Studies 8 (1): 17-34.

Tyler, Imogen. 2013. Revolting Subjects: Social Abjection and Resistance in Neoliberal Britain. London: Zed. 